\title{
Changes in Ice Cover Duration and Maximum Ice Thickness for Rivers and Lakes in the Asian Part of Russia
}

\author{
Valery Vuglinsky, Dmitry Valatin \\ St. Petersburg State University, St. Petersburg, Russia \\ Email: vvuglins@vv4218.spb.edu
}

How to cite this paper: Vuglinsky, V. and Valatin, D. (2018) Changes in Ice Cover Duration and Maximum Ice Thickness for Rivers and Lakes in the Asian Part of Russia. Natural Resources, 9, 73-87.

https://doi.org/10.4236/nr.2018.93006

Received: January 30, 2018

Accepted: March 25, 2018

Published: March 28, 2018

Copyright $\odot 2018$ by authors and Scientific Research Publishing Inc. This work is licensed under the Creative Commons Attribution International License (CC BY 4.0).

http://creativecommons.org/licenses/by/4.0/

\begin{abstract}
This article is concerned with assessment of changes in two critical characteristics of lake and river ice regime, namely ice cover duration and maximum ice thickness, in the period from the beginning of the 80 s to the present, which is characterized by higher temperatures in the Northern Hemisphere compared with the previous period. The above ice regime characteristics are often limiting factors in winter operation of lakes and rivers (navigation, hydraulic construction works in cold period, construction of ice roads etc.). Assessment of changes in ice characteristics of lakes and rivers has been made for 52 river and five lake gauging sites of the Asian part of Russia (APR) using long-term observation data from the Russian observing network. Long-term series of the above characteristics were divided into two periods: from 1955 to 1979 (the period of stationary climate) and from 1980 to 2014 (non-stationary climate) and assessed from the point of view of their homogeneity and trend significance by Student's t-test. The research has found that at most of the sites in the APR, both ice cover duration and maximum ice thickness decreased during non-stationary climate period compared with the previous one. The greatest quantitative changes have occurred in the Eastern Siberia (average net decrease in ice cover duration amounted to 7 days.decade ${ }^{-1}$ and in maximum ice thickness- $20 \mathrm{~cm} \cdot$ decade $^{-1}$ ) and in the Amur River basin (7 days.decade ${ }^{-1}$ and $17 \mathrm{~cm} \cdot$ decade $^{-1}$ respectively).
\end{abstract}

\section{Keywords}

Ice Regime, Rivers, Lakes, Asian Part of Russia, Changes, Last Three Decades

\section{Introduction}

Global climate warming, primarily occurring as increases in global air tempera- 
tures, is affecting many natural processes, including hydrological regime of rivers and lakes. Each successive decade is characterized by higher temperatures compared with previous one, and the last three decades have been considered the warmest for more than one thousand years in the Northern Hemisphere [1]. Ice characteristics of inland water bodies are among the most sensitive to air temperature changes.

Early studies of changes in ice regime of water bodies due to changing climate began in Russia in the last decade of the twentieth century with large rivers in various geographic zones of the country. Scientists first explored the relationships of freeze-up and break-up dates with variations in air temperature and their changes in the last decades. The next step was to assess shifts in the dates of ice appearance and breaking, as well as of changes in ice cover duration and maximum ice thickness for rivers and lakes of the Russian Federation. The history of research of changes in ice regime of the Russian lakes and rivers under changing climate is summarized by Vuglinsky [2]. Studies have shown that, for lakes and rivers of different sizes and locations, changes in ice characteristics can be divergent, however, for most of the Russian lakes and rivers examined, a distinct general decreasing tendency in the ice cover duration and maximum ice cover thickness has been observed over the last 30 - 35 years.

This article summarizes the results of assessments of changes in ice cover duration and maximum ice thickness for lakes and rivers of the Asian part of Russia (APR). These studies are a continuation of those summarized in [2] [3] [4].

The Asian part of Russia comprises more than $75 \%$ of the whole territory of the country. It is located to the east of the Urals and covers about 13 million $\mathrm{km}^{2}$. Due to considerable extent, physiographic features of the APR vary widely [5]. There are four large natural regions within the APR: Western Siberia, Eastern Siberia, The Far East and The Amur River region.

Western Siberia stretches from the Urals as far as the Central Siberian Plateau. It has a continental climate with minimum winter temperatures of $-52^{\circ} \mathrm{C}$ throughout the whole territory. Average winter temperature in the southern part of the territory is $-15^{\circ} \mathrm{C}$, while in the northern part it is $-30^{\circ} \mathrm{C}$. The air temperature amplitude increases and precipitation amount decreases from north to south which is an indication of increasing continentality southwards.

Eastern Siberia covers most part of the Central Siberian Plateau. The climate is extremely continental. Average temperature in January is from $-17^{\circ} \mathrm{C}$ in Krasnoyarsk to $-40^{\circ} \mathrm{C}$ in Yakutsk. Almost the entire territory is permafrost which forms during long and extremely cold, dry winters.

The Far East includes North-Eastern Siberia and the so-called North Pacific country divided by the Pacific watershed.

The climate of the North-Eastern Siberia is harsh, extremely continental due to location of the territory in arctic and subarctic zones, as well as the protection from the impact of the Pacific by mountains. Average temperature in January is $-40^{\circ} \mathrm{C}$ over the entire territory excluding lowlands in the north where average 
temperature is $-50^{\circ} \mathrm{C}$ and occasionally $-60^{\circ} \mathrm{C}$.

The North Pacific country is located in three climate zones: arctic, subarctic and temperate. Average temperature in January varies from $-4^{\circ} \mathrm{C}$ on the Kuril Islands to $-25^{\circ} \mathrm{C}$ in the Central Kamchatka depression.

The Amur River region covers the eastern edge of Asia and includes (apart from the mainland area) the Sakhalin, the Shantarskie and the Kuril Islands. The climate is monsoon, with $90 \%$ of annual precipitation observed in warm period and the rest in the cold period. Average temperature in January varies from $-9^{\circ} \mathrm{C}$ in the south of the Sakhalin Island to $-30^{\circ} \mathrm{C}$ in the upper reaches of the Amur River. The climate of the mountainous area is colder and wetter.

\section{Data and Methodology}

As stated above, ice cover duration and maximum ice thickness were selected as ice regime characteristics. Ice cover duration is determined from difference between dates of persistent ice cover beginning and end [6]. Data on ice cover duration and maximum ice thickness were taken from hydrological year-books and water inventory.

The study uses long-term observation data for 52 river and 5 lake hydrological observing sites. These were selected in various parts of the APR to ensure the full consideration of the diverse ice formation conditions in different regions of the area. Figure 1 provides the location of the sites.

Since one of the tasks of this study was to analyze changes in ice regime characteristics under changing climate, long-term data series were divided into two periods: from 1955 to 1979 (the period of stationary climate) and from 1980 to

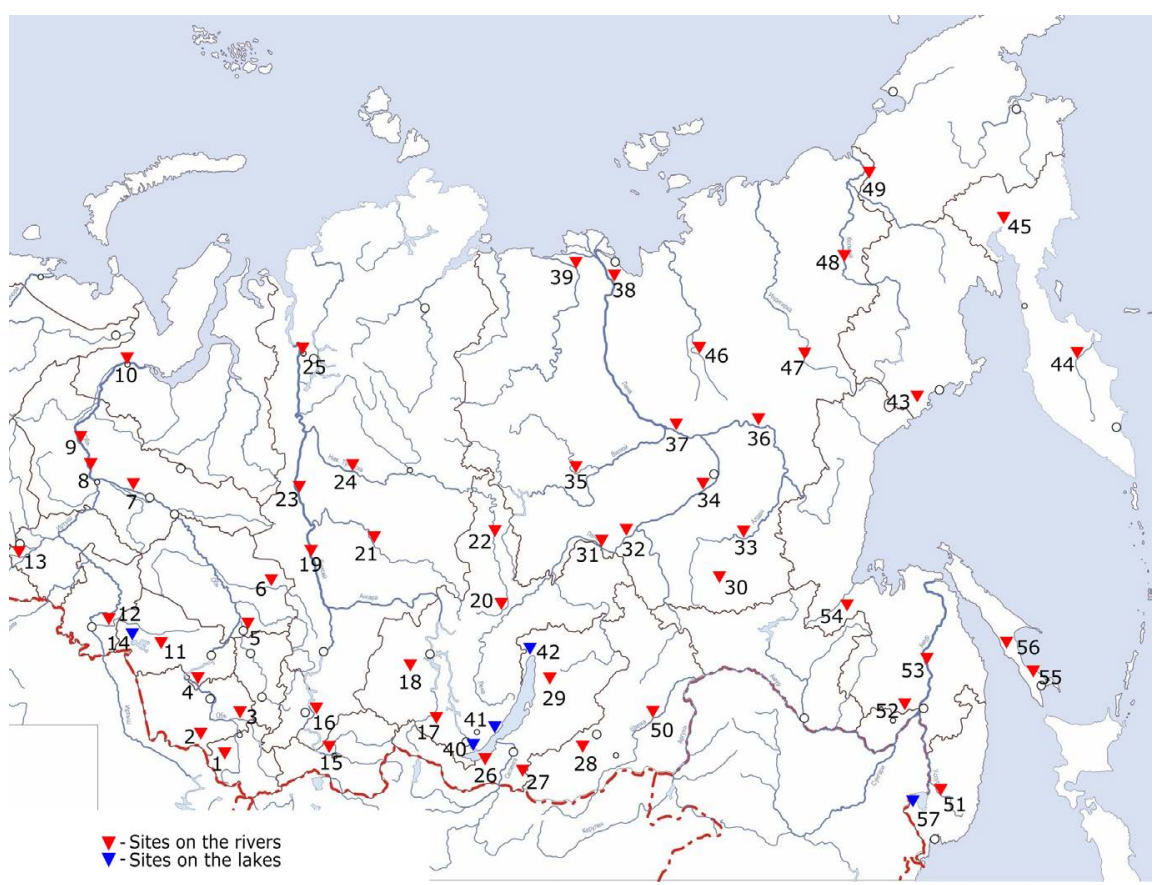

Figure 1. River and lake site location. 
2014 (non-stationary climate). Such a division is defined by the fact that, according to many researchers [7] [8] [9] [10], the most prominent climate changes have occurred in Russia at the end of the '70s-beginning of the '80s. These periods were identified in series of maximum ice thickness and ice cover duration for lake stations and in series of maximum ice thickness for river stations. As observations of ice cover duration on rivers only started in the late 1970s, this parameter was analyzed only within the period 1980-2014.

The entire initial dataset was incorporated into an electronic database. All subsequent work on scientific analysis, generalization and interpretation of data used the compiled database.

Information on selected hydrological sites and observation periods used for calculations is summarized in Table 1 . Site numbering corresponds to the numbers of sites on the map.

The methodology included the analysis of homogeneity of long-term series, comparison of mean values of time series over the two selected periods, identification of trend components in the time series for the period of non-stationary climate (1980-2014) and, finally, in quantitative assessment of the observed changes in ice regime characteristics of lakes and rivers in the APR for the period 1980-2014 compared with the previous one.

\section{Assessment of Homogeneity of Long-Term Ice-Regime Series}

Homogeneity of long-term ice-regime series was assessed using Student's t-test which takes account of degree to which mean values of the two parts of the series differ [11].

For river sites, only homogeneity of maximum ice thickness was assessed because, as it was mentioned above, data on ice cover duration were available only from 1970.

The results of the analysis of the homogeneity of long-term maximum ice thickness data series for the rivers of the APR demonstrated that more than half of the series ( 28 out of 52 ) proved non-homogeneous with $5 \%$ error probability.

It is remarkable that the greatest ratio of non-homogeneous series ( 9 out of 12 or $75 \%$ ) is typical for sites in the Ob' River basin, i.e. the western part of the territory. The ratio of such sites decreases eastwards (6 out of 11 or $55 \%$ in the Yenisei River basin, 7 out of $14 \%$ or $50 \%$ in the Lena basin, 3 out of 7 or $43 \%$ in the Amur River region and in the Kolyma River basin time series proved homogeneous for all observing sites). The reasons behind non-homogeneity of river data series in different parts of the APR are different. It may be caused by considerable variations in gradients of trends for the two periods, which is the main reason for non-homogeneity for most of the sites in the Ob' River basin, or by the divergence of the trends. The latter also causes non-homogeneity of the series for the Lena and Yenisei basins.

Assessment of homogeneity of long-term lake series included both maximum 
Table 1. Observing sites on lakes and rivers and length of observing periods.

\begin{tabular}{|c|c|c|c|c|}
\hline \multirow{2}{*}{$\begin{array}{l}\text { Number on } \\
\text { the map } \\
\text { (Figure 1) }\end{array}$} & \multirow[b]{2}{*}{ River (r)/lake (l)—site } & \multirow{2}{*}{$\begin{array}{c}\text { Area, } \mathrm{km}^{2} \\
\text { (river watershed/lake) }\end{array}$} & \multicolumn{2}{|c|}{ Observing periods } \\
\hline & & & $\begin{array}{l}\text { Ice cover } \\
\text { duration }\end{array}$ & $\begin{array}{c}\text { Maximum ice } \\
\text { thickness }\end{array}$ \\
\hline \multicolumn{5}{|c|}{ Western Siberia } \\
\hline 1 & r.Ursul—Ongudai & 3080 & $1980-2014$ & $1955-2014$ \\
\hline 2 & r.Alei-Lokot & 6450 & $1980-2014$ & $1955-2014$ \\
\hline 3 & r.Biya-Biysk & 36,900 & $1980-2014$ & $1955-2014$ \\
\hline 4 & r.Ob'-Kamen-na-Obi & 216,000 & $1980-2014$ & $1955-2014$ \\
\hline 5 & r.Tom'-Tomsk & 57,800 & $1980-2014$ & $1955-2014$ \\
\hline 6 & r.Ket'-Maksimkin Yar & 38,400 & $1980-2014$ & $1955-2014$ \\
\hline 7 & r.Ob'-Sytomino & $1,000,000$ & $1980-2014$ & $1955-2014$ \\
\hline 8 & r.Ob'-Belogorye & $2,690,000$ & $1980-2014$ & $1955-2014$ \\
\hline 9 & r.Ob'-Oktyabrskoye & $2,720,000$ & $1980-2014$ & $1955-2014$ \\
\hline 10 & r.Ob'-Salekhard & $2,950,000$ & $1980-2014$ & $1955-2014$ \\
\hline 11 & r.Kargat-Gavrilovskoye & 3910 & $1980-2014$ & $1955-2014$ \\
\hline 12 & r.Om'-Kalachinsk & 51,300 & $1980-2014$ & $1955-2014$ \\
\hline 13 & r.Iset'-Isetskoye & 56,000 & $1980-2014$ & $1955-2014$ \\
\hline 14 & 1.Chany-Kvashino & 1030 & $1955-2014$ & $1955-2014$ \\
\hline \multicolumn{5}{|c|}{ Eastern Siberia } \\
\hline 15 & r.Yenisei-Kyzyl & 126,000 & $1980-2014$ & $1955-2014$ \\
\hline 16 & r.Yenisei-Selivanikha & $2,340,000$ & $1980-2014$ & $1955-2014$ \\
\hline 17 & r.Khaita-Khaita & 1970 & $1980-2014$ & $1955-2014$ \\
\hline 18 & r.Iya-Tulun & 14,500 & $1980-2014$ & $1955-2014$ \\
\hline 19 & r.Yenisei-Vorogovo & $1,510,000$ & $1980-2014$ & $1955-2014$ \\
\hline 20 & r.Nizhniaya Tunguska-Podvoloshino & 8270 & $1980-2014$ & $1955-2014$ \\
\hline 21 & r.Podkamennaya Tunguska-Baikit & 159,000 & $1980-2014$ & 1955-2014 \\
\hline 22 & r.Nizhniaya Tunguska-Yerbogachen & 77,400 & $1980-2014$ & $1955-2014$ \\
\hline 23 & r.Yenisei-Vereshchagino & $1,850,000$ & $1980-2014$ & $1955-2014$ \\
\hline 24 & r.Nizhniaya Tunguska-Bolshoi Porog & 438,000 & $1980-2014$ & $1955-2014$ \\
\hline 25 & r.Yenisei-Dudinka & $2,480,000$ & $1980-2014$ & $1955-2014$ \\
\hline 26 & r.Khara-Murin-Murino & 1130 & $1980-2014$ & $1955-2014$ \\
\hline 27 & r.Tchikoi-Gremyachka & 15,600 & $1980-2014$ & $1955-2014$ \\
\hline 28 & r.Ingoda-Ulyoty & 12,500 & $1980-2014$ & $1955-2014$ \\
\hline 29 & r.Barguzin-Mogoito & 9350 & $1980-2014$ & $1955-2014$ \\
\hline 30 & r.Timpton-Ust'-Baralas & 13,300 & $1980-2014$ & $1955-2014$ \\
\hline 31 & r.Lena-Macha & 538,000 & $1980-2014$ & $1955-2014$ \\
\hline 32 & r.Biriuk-Biriuk & 9700 & $1980-2014$ & $1955-2014$ \\
\hline 33 & r.Aldan-Ugino & 102,000 & $1980-2014$ & $1955-2014$ \\
\hline
\end{tabular}




\section{Continued}

\begin{tabular}{|c|c|c|c|c|}
\hline 34 & r.Lena-Pokrovskoye & 892,000 & $1980-2014$ & $1955-2014$ \\
\hline 35 & r.Markha-Malykai & 89,600 & $1980-2014$ & $1955-2014$ \\
\hline 36 & r.Aldan-Krest-Khaldzhay & 660,000 & $1980-2014$ & $1955-2014$ \\
\hline 37 & r.Lena-Sangar & $1,680,000$ & $1980-2014$ & 1955-2014 \\
\hline 38 & r.Lena-Kyusyur & $2,430,000$ & $1980-2014$ & $1955-2014$ \\
\hline 39 & r.Olenek_Tiumyati & 198,000 & $1980-2014$ & 1955-2014 \\
\hline 40 & 1.Baikal_Baikal & 31,500 & $1955-2014$ & $1955-2014$ \\
\hline 41 & 1.Baikal-Peschanaya Bukhta & 31,500 & $1955-2014$ & $1955-2014$ \\
\hline 42 & 1.Baikal-Nizhneangarsk & 31,500 & $1955-2014$ & $1955-2014$ \\
\hline \multicolumn{5}{|c|}{ The Far East } \\
\hline 43 & r.Taui-Talon & 25,100 & $1980-2014$ & 1955-2014 \\
\hline 44 & r.Kamchatka-Kliuchi & 45,600 & $1980-2014$ & $1955-2014$ \\
\hline 45 & r.Penzhina-Kamenskoye & 71,600 & $1980-2014$ & 1956-2014 \\
\hline 46 & r.Yana-Verkhoyansk & 45,300 & $1980-2014$ & $1955-2014$ \\
\hline 47 & r.Indigirka-St. Iurty & 51,100 & $1980-2014$ & $1955-2014$ \\
\hline 48 & r.Kolyma-Zyryanka & 287,000 & $1980-2014$ & 1955-2014 \\
\hline 49 & r.Maly Aniuy_Aniuysk & 48,600 & $1980-2014$ & $1957-2014$ \\
\hline \multicolumn{5}{|c|}{ The Amur River region } \\
\hline 50 & r.Shilka-Sretensk & 175,000 & $1980-2014$ & $1955-2014$ \\
\hline 51 & r.Ussuri-Kirovskiy & 24,400 & $1980-2014$ & 1956-2014 \\
\hline 52 & r.Urmi-Verkhnie Urmi & 1350 & $1980-2014$ & $1955-2014$ \\
\hline 53 & r.Amur-Komsomolsk-na-Amure & $1,730,000$ & $1980-2014$ & 1955-2014 \\
\hline 54 & r.Uda-Udskoye & 37,500 & $1980-2014$ & $1955-2014$ \\
\hline 55 & r.Naiba-Bykov & 679 & $1980-2014$ & 1955-2014 \\
\hline 56 & r.Uglegorka-Krasnopolye & 865 & $1980-2014$ & $1955-2014$ \\
\hline 57 & 1.Khanka-Astrakhanka & 4070 & $1955-2014$ & $1955-2014$ \\
\hline
\end{tabular}

ice thickness and ice cover duration. Long-term series for four out of five gauging sites do not meet the hypothesis of homogeneity with a probability of 0.95 for both characteristics. Long-term series for both characteristics have proved homogeneous only for Peschanaya Bukhta on the Lake Baikal.

Since there is a certain relationship between maximum ice thickness and ice cover duration, one can suppose that, once non-homogeneity has been revealed for maximum ice thickness, long-term series of ice cover duration would prove non-homogeneous as well for the same gauging site. Such consistency is proved by the results of homogeneity analysis for lake series: the identified homogeneity (or non-homogeneity) of a long-term series for one of the characteristics was accompanied by the same result for another one at the same gauging site.

Given below as an example are results of the homogeneity assessment for 
maximum ice thickness series for the rivers of the Western Siberia (Table 2). As can be seen from the table, long-term series do not meet the homogeneity hypothesis with probability of 0.95 for nine out of twelve sites.

\section{Assessment of Trends of Long-Term Series of Ice Regime Characteristics}

For assessments of trend significance, the Student's test method based on a hypothesis stipulating that regression coefficients are equal to zero was used.

Homogeneity of trends in ice cover duration series for river sites was assessed for the period 1980-2014 and trends in maximum ice thickness and ice cover duration for lake sites-for three periods: 1955-1979, 1980-2014 and for the entire period from 1955 to 2014.

The results of the assessment of trend significance demonstrated that for most of the ice cover duration series on river sites (for 37 out of 52) significant trends have been obtained. All of them are negative and confirm the results of other researches indicating reduction of ice cover duration on the rivers of the APR. Regions with the highest rate of significant trends in ice cover duration include: the Amur River region (>95\%), Eastern Siberia (80\%) and the Far East (about 70\%). Table 3 provides the results of assessment of trend significance for the period 1980-2014 with respect to river sites located in the Amur River basin.

Assessment of ice cover duration trend significance showed that most of the significant trends refer to the entire period 1955-2014. This indicates that reduction of ice cover duration has occurred over the entire time period (the last 50 60 years), which is consistent with results presented in [2].

Table 2. Assessment of homogeneity of maximum ice thickness series for the rivers of the Western Siberia.

\begin{tabular}{|c|c|c|c|c|}
\hline \multirow{2}{*}{$\begin{array}{l}\text { Number on } \\
\text { the map } \\
\text { (Figure 1) }\end{array}$} & \multirow{2}{*}{ River-site } & \multicolumn{2}{|c|}{ Student's criteria } & \multirow{2}{*}{$\begin{array}{c}\text { Homogeneous/ } \\
\text { Non-homogeneous }\end{array}$} \\
\hline & & $\begin{array}{c}\text { Calculated } \\
\text { value }\end{array}$ & Critical value & \\
\hline 1 & Ursul-Ongudai & 5.018 & 2.002 & Non-homogeneous \\
\hline 2 & Alei-Lokot & 1.530 & 2.002 & Homogeneous \\
\hline 3 & Biya-Biysk & 3.133 & 2.002 & Non-homogeneous \\
\hline 4 & Ob'-Kamen-na-Obi & 5.987 & 2.002 & Non-homogeneous \\
\hline 5 & Tom'-Tomsk & 1.913 & 2.002 & Homogeneous \\
\hline 6 & Ket'-Maksimkin Yar & 0.770 & 2.002 & Homogeneous \\
\hline 7 & Ob'-Sytomino & 5.938 & 2.002 & Non-homogeneous \\
\hline 8 & Ob'-Belogorye & 2.443 & 2.002 & Non-homogeneous \\
\hline 9 & Ob’-Oktyabrskoye & 2.672 & 2.002 & Non-homogeneous \\
\hline 10 & Ob'-Salekhard & 2.101 & 2.002 & Non-homogeneous \\
\hline 11 & Kargat-Gavrilovskoye & 6.267 & 2.002 & Non-homogeneous \\
\hline 12 & Om'-Kalachinsk & 11.840 & 2.002 & Non-homogeneous \\
\hline
\end{tabular}


Table 3. Results of assessment of trend significance for ice cover duration for the period 1980-2014 (sites located in the Amur River basin).

\begin{tabular}{cccc}
\hline $\begin{array}{c}\text { Number on the } \\
\text { map } \\
(\text { Fig.1 })\end{array}$ & River-site & \multicolumn{2}{c}{ Student's criteria } \\
\cline { 3 - 4 } 50 & Shilka-Sretensk & Calculated value & Critical value \\
\hline 51 & Ussuri-Kirovskiy & $-\mathbf{5 . 0 7 4}$ & 2.035 \\
52 & Urmi-Verkh. Urmi & $-\mathbf{3 . 3 6 0}$ & 2.035 \\
53 & Amur-Komsomolsk-na-Amure & $-\mathbf{2 . 8 0 0}$ & 2.035 \\
54 & Uda-Udskoye & $-\mathbf{3 . 9 0 2}$ & 2.035 \\
55 & Naiba-Bykov & $-\mathbf{3 . 7 3 8}$ & 2.035 \\
56 & Uglegorka-Krasnopolye & $-\mathbf{4 . 0 5 7}$ & 2.035 \\
\hline
\end{tabular}

Similar situation is observed in assessment of maximum ice thickness trend significance. For more than half of river sites ( 30 out of 52 ), significant trends with negative regression coefficient refer to the period 1955-2014, much fewer-to the period 1980-2014 and only 14 sites-to the period 1955-1979. With respect to lakes, significant negative trends are also typical for the entire period 1955-2014.

It is also important to note that most of the long-term series of those lake and river sites for which significant trends have been identified in the period 1955-2014 proved non-homogeneous.

\section{Assessment of Quantitative Changes in Ice Regime Characteristics for Non-Stationary Climate Period}

\subsection{Assessment of Changes Occurred in 1980-2014}

Quantitative assessments of changes in ice regime characteristics of rivers of the APR have been made for non-stationary climate period (1980-2014) using graphic charts, as shown in Figure 2.

In this charts, values corresponding to the last and the first years of a long-term series were read off the trend lines. Difference between these marks referred to the number of years in a series characterizes a gradient $(\phi)$ of changes in this particular characteristic over time. For ease of interpretation, the gradient was calculated with reference to a ten-year period and expressed in $\mathrm{cm} \cdot \mathrm{decade}^{-1}$ for maximum ice thickness series and in day.decade ${ }^{-1}$ for ice cover duration series (where a decade is a ten-year period).

Analysis of the results of assessing trends in ice cover duration for lake and river sites for the period 1980-2014 demonstrated that for all of the sites except for two of them (Ob'-Belogorye and Baikal-Peschanaya Bukhta) the gradient proved negative. As for the positive trends revealed for these two sites, they were negligible.

The greatest changes in ice cover duration were found for the Amur River ba$\sin (-5.47$ days over a decade) and for the Far East ( -4.63 days over a decade). The greatest absolute changes occurred at Penzhina-Kamenskoye, where ice 


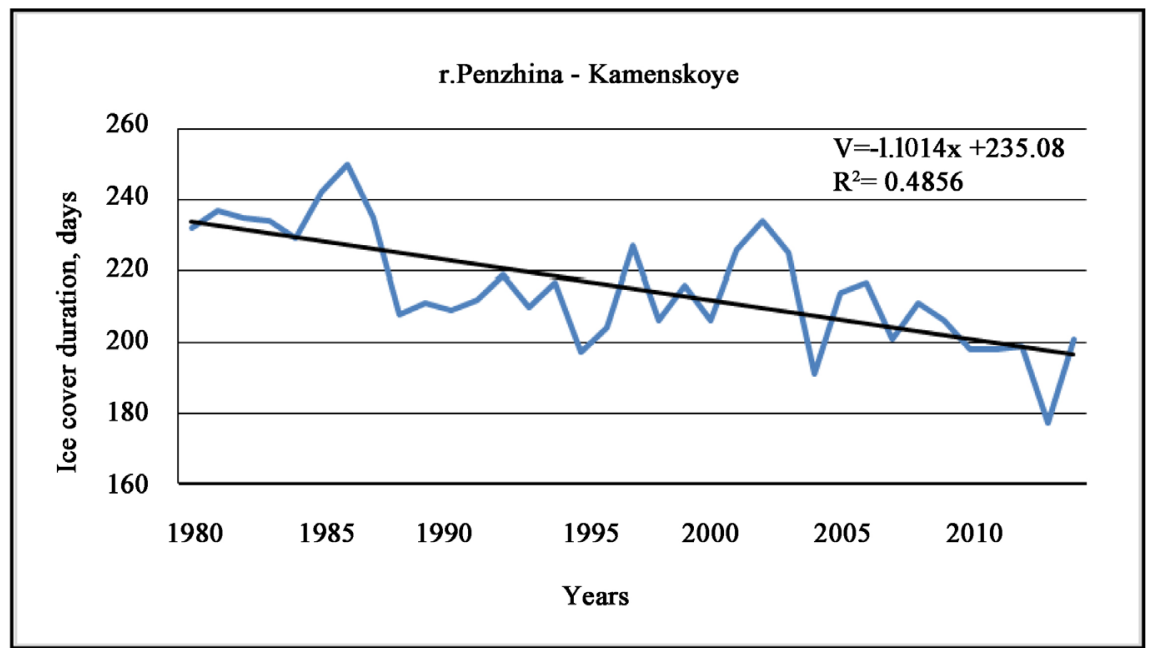

Figure 2. Graphic chart of changes in ice cover duration at Penzhina-Kamenskoye for the period 1980-2014.

cover duration reduced by 38 days for 1980-2014 or by 11 days for a decade on average, and at Naiba-Bykov, where ice cover duration reduced by 36 days or 10 days for a decade on average (corresponding trends assessed as significant).

Unlike ice cover duration series, maximum ice thickness series had much more positive gradients-for 16 sites out of 57 . However, these trends proved significant only for three sites out of 16: Yenisei-Vorogovo; Ingoda-Ulety; and Baikal-Peschanaya Bukhta.

The greatest negative average decadal trend changes in maximum ice thickness are typical for the sites of the Far East (Taui-Talon: $-13.6 \mathrm{~cm} \cdot \mathrm{decade}^{-1}$; Indigirka-Iurty: $-10.35 \mathrm{~cm} \cdot$ decade $^{-1}$; Yana-Verkhoyansk: $-9.91 \mathrm{~cm} \cdot$ decade $^{-1}$ ).

Table 4 provides data on typical trend changes in maximum ice thickness for the period 1980-2014 for selected lake and river sites located in the territory of the four APR regions considered.

\subsection{Assessment of Changes in Mean Values for the Two Considered Periods}

Assessments of changes in ice regime characteristics over the period 1980-2014 obtained from the analysis of graphic charts, as presented in 5.1, still do not provide objective view of the past changes in these characteristics compared with the previous period. Account must also be taken of differences in their means for the two periods selected. Such assessments were made for series of maximum ice thickness for all lake and river sites and for the series of ice cover duration only for lake sites because ice cover duration data for river sites for the period until 1980 are not available.

Analysis of difference $(\Delta)$ between mean values for the second period 1980-2014 $\left(\mathrm{X}_{2}\right)$ compared with the first period 1955-1979 $\left(\mathrm{X}_{1}\right)$ demonstrated that for the most sites both on lakes and rivers they proved negative, i.e. a reduction of means took place in the second period. The exception were the three sites with 
Table 4. Results of the assessment of trend changes in maximum ice thickness for the period 1980-2014.

\begin{tabular}{|c|c|c|c|c|c|}
\hline $\begin{array}{l}\text { Number } \\
\text { on a map } \\
\text { (Figure } 1 \text { ) }\end{array}$ & River/Lake-Site & $\begin{array}{c}\text { Value read } \\
\text { off the trend } \\
\text { line }(1980)\end{array}$ & $\begin{array}{l}\text { Value read } \\
\text { off the trend } \\
\text { line }(2014)\end{array}$ & $\begin{array}{c}\text { Change, } \\
\mathrm{cm}\end{array}$ & $\begin{array}{c}\phi \\
\left(\mathrm{cm} \cdot \mathrm{decade}^{-1}\right)\end{array}$ \\
\hline \multicolumn{6}{|c|}{ Western Siberia } \\
\hline 1 & Ursul_-Ongudai & 100.07 & 69.47 & -30.60 & -8.74 \\
\hline 5 & Tom'-Tomsk & 88.32 & 64.76 & -23.56 & -6.73 \\
\hline 7 & Ob'-Sytomino & 82.89 & 66.31 & -16.57 & -4.73 \\
\hline 10 & Ob'-Salekhard & 106.22 & 94.47 & -11.75 & -3.36 \\
\hline 11 & Kargat-Gavrilovskoye & 57.51 & 78.14 & 20.63 & 5.89 \\
\hline \multicolumn{6}{|c|}{ Eastern Siberia } \\
\hline 19 & Yenisei-Vorogovo & 76.20 & 96.71 & 20.51 & 5.86 \\
\hline 22 & Nizhniaya Tunguska-Yerbogachen & 83.65 & 66.24 & -17.41 & -4.97 \\
\hline 28 & Ingoda-Ulyoty & 120.56 & 140.36 & 19.80 & 5.66 \\
\hline 31 & Lena-Macha & 100.27 & 82.41 & -17.86 & -5.10 \\
\hline 32 & Biriuk-Biriuk & 117.58 & 91.97 & -25.61 & -7.32 \\
\hline 37 & Lena-Sangar & 178.42 & 144.38 & -34.05 & -9.73 \\
\hline \multicolumn{6}{|c|}{ The Far East } \\
\hline 43 & Taui-Talon & 121.37 & 73.78 & -47.59 & -13.60 \\
\hline 44 & Kamchatka-Kliuchi & 108.10 & 87.38 & $-20,72$ & -5.92 \\
\hline 46 & Yana-Verkhoyansk & 155.85 & 121.18 & -34.68 & -9.91 \\
\hline 47 & Indigirka-Iurty & 190.26 & 226.48 & 36.22 & 10.35 \\
\hline \multicolumn{6}{|c|}{ The Amur River region } \\
\hline 52 & Urmi-Verkh. Urmi & 93.98 & 120.42 & 26.44 & 7.55 \\
\hline 53 & Amur-Komsomolsk-na -Amure & 117.96 & 95.19 & -22.77 & -6.51 \\
\hline 54 & Uda-Udskoye & 114.29 & 96.57 & -17.71 & -5.06 \\
\hline 56 & Uglegorka-Krasnopolye & 85.77 & 57.26 & -28.50 & -8.14 \\
\hline
\end{tabular}

positive changes in mean values of maximum ice thickness: Barguzin-Mogoito $(+13 \mathrm{~cm})$, Kamchatka-Kliuchi $(+10 \mathrm{~cm})$ and Kolyma-Zyryanka $(+4 \mathrm{~cm})$. River sites with the greatest negative values of $\Delta$ for maximum ice thickness $(\geq$ $-15 \mathrm{~cm}$ ) are listed in Table 5 .

\subsection{Assessment of Net Changes in Ice Characteristics for the Non-Stationary Climate Period}

Net changes in the considered ice regime characteristics for the non-stationary climate period (1980-2014) compared with the previous period (1955-1979) were determined by comparing the results of trend assessment of changes for the period 1980-2014 obtained by using the chart diagrams (5.1) with the results of assessment of differences in means for the two considered periods (5.2). Analysis 
Table 5. River sites with the greatest negative values of $\Delta$ for maximum ice thickness.

\begin{tabular}{|c|c|c|c|c|}
\hline $\begin{array}{c}\text { Number on the map } \\
\text { (Figure 1) }\end{array}$ & River-site & $\mathrm{X}_{1}, \mathrm{~cm}$ & $\mathrm{X}_{2}, \mathrm{~cm}$ & $\Delta, \mathrm{cm}$ \\
\hline 1 & Ursul-Ongudai & 118 & 85 & -33 \\
\hline 4 & Ob'-Kamen-na-Obi & 92 & 72 & -20 \\
\hline 7 & Ob'-Sytomino & 90 & 75 & -15 \\
\hline 11 & Kargat-Gavrilovskoye & 92 & 68 & -24 \\
\hline 12 & Om'-Kalachinsk & 78 & 51 & -27 \\
\hline 15 & Yenisei-Kyzyl & 158 & 121 & -37 \\
\hline 17 & Khaita-Khaita & 123 & 107 & -16 \\
\hline 24 & Nizhniaya Tunguska-Bolshoi Porog & 119 & 98 & -21 \\
\hline 26 & Khara-Murin-Murino & 76 & 60 & -16 \\
\hline 31 & Lena-Macha & 106 & 91 & -15 \\
\hline 36 & Aldan-Krest-Khaldzhai & 147 & 131 & -16 \\
\hline 37 & Lena-Sangar & 195 & 161 & -34 \\
\hline 38 & Lena-Kyusyur & 194 & 153 & -41 \\
\hline 39 & Olenek-Tiumyati & 151 & 135 & -16 \\
\hline 47 & Indigirka-Iurty & 237 & 208 & -29 \\
\hline 52 & Urmi-Verkh. Urmi & 129 & 107 & -22 \\
\hline 53 & Amur-Komsomolsk-na -Amure & 128 & 107 & -21 \\
\hline
\end{tabular}

of the data showed that, for most of the sites, a decline in both ice cover duration and maximum ice thickness is observed. The exceptions were: the six sites in the Eastern Siberia (Yenisei-Vorogovo; Ingoda-Ulyoty; Barguzin-Mogoito; Aldan-Ugino; Lena-Pokrovskoye and Baikal-Peschanaya Bukhta); two sites in the Far East (Indigirka-Iurty, Kolyma-Zyrianka); and one in the Amur River basin (Urmi-Verkh. Urmi). At all the above sites, except for Baikal-Peschanaya Bukhta, an increase in the maximum ice thickness has been observed. At the Peschanaya Bukhta site, only ice cover duration has increased.

Consolidated calculated values of estimated changes in ice cover duration and maximum ice thickness for non-stationary climate period (1980-2014) adjusted to a scatter band of $\pm 10 \%$ of a mean are listed in Table 6 . For the entire territory of the Asian part of Russia, a distinct general decreasing trend in ice cover duration and maximum ice thickness for the period 1980-2014 compared with the previous period is observed. The greatest changes in the considered ice regime characteristics occurred in the Eastern Siberia where average net decrease in ice cover duration amounted to 7 days. decade $^{-1}$ and in maximum ice thickness-20 $\mathrm{cm} \cdot$ decade $^{-1}$. In the Amur River basin such decrease amounted to 7 days.decade ${ }^{-1}$ and $17 \mathrm{~cm} \cdot$ decade $^{-1}$ respectively.

\section{Conclusions}

Assessment of changes in ice regime of rivers and lakes under non-stationary 
Table 6. Consolidated calculated values of changes in ice cover duration and maximum ice thickness for the period 1980-2014 compared with the previous period.

\begin{tabular}{|c|c|c|c|}
\hline $\begin{array}{l}\text { Number on } \\
\text { the map } \\
\text { (Figure 1) }\end{array}$ & River/Lake-Site & $\begin{array}{c}\text { Changes in ice cover } \\
\text { duration }{ }^{\star} \text {, days }\end{array}$ & $\begin{array}{l}\text { Changes in } \\
\text { maximum ice } \\
\text { thickness, } \mathrm{cm}\end{array}$ \\
\hline 1 & 2 & 3 & 4 \\
\hline \multicolumn{4}{|c|}{ Western Siberia } \\
\hline 1 & Ursul-Ongudai & $-23-29$ & $-57-70$ \\
\hline 2 & Alei-Lokot & $-13-16$ & $-8-10$ \\
\hline 3 & Biya-Biysk p. & $-18-22$ & $-3-4$ \\
\hline 4 & Ob'-Kamen-na-Obi & $-7-8$ & $-21-25$ \\
\hline 5 & Tom-Tomsk & $-14-17$ & $-28-35$ \\
\hline 6 & Ket'-Maksimkin Yar & $-6-8$ & $-7-9$ \\
\hline 7 & Ob'-Sytomino & $-3-4$ & $-28-35$ \\
\hline 8 & Ob'-Belogorye & $+6+7$ & $-9-11$ \\
\hline 9 & Ob'-Oktyabrskoye & $-14-17$ & $-14-17$ \\
\hline 10 & Ob'-Salekhard & $-9-11$ & $-19-23$ \\
\hline 11 & Kargat-Gavrilovskoye & $-17-21$ & $-3-4$ \\
\hline 12 & Om'-Kalachinsk & $-20-25$ & $-27-33$ \\
\hline 13 & Iset-Isetskoye & $-19-24$ & $-20-24$ \\
\hline 14 & Chany_Kvashino & $-36-44$ & $-11-13$ \\
\hline \multicolumn{4}{|c|}{ Eastern Siberia } \\
\hline 15 & Yenisei-Kyzyl & $-12-15$ & $-38-46$ \\
\hline 16 & Yenisei-Selivanikha & $-15-18$ & $-7-8$ \\
\hline 17 & Khaita-Khaita & $-6-7$ & $-28-34$ \\
\hline 18 & Iya-Tulun & $-12-15$ & $-13-16$ \\
\hline 19 & Yenisei-Vorogovo & $-15-19$ & $+9+12$ \\
\hline 20 & Nizhniaya Tunguska_Podvoloshino & $-10-12$ & $-8-10$ \\
\hline 21 & Podkamennaya Tunguska_-Baikit & $-19-24$ & $-13-16$ \\
\hline 22 & Nizhniaya Tunguska-Yerbogachen & $-9-12$ & $-24-29$ \\
\hline 23 & Yenisei-Vereshchagino & $-12-14$ & $-24-30$ \\
\hline 24 & Nizhniaya Tunguska-Bolshoi Porog & $-13-16$ & $-6-7$ \\
\hline 25 & Yenisei-Dudinka & $-9-11$ & $-11-14$ \\
\hline 26 & Khara-Murin-Murino & $-14-17$ & $-13-16$ \\
\hline 27 & Tchikoi-Gremyachka & $-8-10$ & $-9-11$ \\
\hline 28 & Ingoda-Ulyoty & $-12-15$ & $+14+17$ \\
\hline 29 & Barguzin-Mogoito & $-17-21$ & $+23+29$ \\
\hline 30 & Timpton-Ust'-Baralas & $-21-25$ & $-6-8$ \\
\hline 31 & Lena-Macha & $-15-19$ & $-30-36$ \\
\hline
\end{tabular}




\section{Continued}

\begin{tabular}{|c|c|c|c|}
\hline 32 & Biriuk-Biriuk & $-15-18$ & $-29-36$ \\
\hline 33 & Aldan-Ugino & $-12-15$ & $+13+16$ \\
\hline 34 & Lena-Pokrovskoye & $-9-11$ & $+2+3$ \\
\hline 35 & Narkha-Malykai & $-8-10$ & $-12-15$ \\
\hline 36 & Aldan-Krest-Khaldzhay & $-10-12$ & $-19-23$ \\
\hline 37 & Lena-Sangar & $-17-21$ & $-61-75$ \\
\hline 38 & Lena-Kyusyur & $-14-17$ & $-49-60$ \\
\hline 39 & Olenek-Tiumyati & $-11-13$ & $-25-30$ \\
\hline 40 & Baikal_-Baikal & $-11-14$ & $-4-5$ \\
\hline 41 & Baikal-Peschanaya Bukhta & $+1+2$ & $-4-5$ \\
\hline 42 & Baikal-Nizhneangarsk & $-12-15$ & $-16-20$ \\
\hline & The Far East & & \\
\hline 43 & Taui-Talon & $-8-10$ & $-47-58$ \\
\hline 44 & Kamchatka-Kliuchi & $-23-28$ & $-10-12$ \\
\hline 45 & Penzhina-Kamenskoye & $-34-41$ & $-6-7$ \\
\hline 46 & Yana-Verkhoyansk & $-6-8$ & $-34-41$ \\
\hline 47 & Indigirka-St. Iurty & $-14-18$ & $+6+8$ \\
\hline 48 & Kolyma-Zyryanka & $-12-15$ & $+7+8$ \\
\hline 49 & Maly Aniuy_Aniuysk & $-4-5$ & $-10-12$ \\
\hline \multicolumn{4}{|c|}{ The Amur River basin } \\
\hline 50 & Shilka-Sretensk & $-6-8$ & $-12-14$ \\
\hline 51 & Ussuri-Kirovskiy & $-22-27$ & $-5-6$ \\
\hline 52 & Urmi-Verkhnie Urmi & $-15-19$ & $+4+5$ \\
\hline 53 & Amur-Komsomolsk-na-Amure & $-7-9$ & $-39-48$ \\
\hline 54 & Uda-Udskoye & $-19-23$ & $-23-28$ \\
\hline 55 & Naiba-Bykov & $-32-39$ & $-8-10$ \\
\hline 56 & Uglegorka-Krasnopolye & $-22-27$ & $-32-39$ \\
\hline 57 & Khanka-Astrakhanka & $-19-24$ & $-10-13$ \\
\hline
\end{tabular}

*Note: changes in ice cover duration for river sites are taken by the results of assessment of trend changes for the period 1980-2014 without consideration of average values for the two periods.

climate conditions over the last 3 - 4 decades contributes to the critical issue of detecting changes in environmental components under changing climate. Ice cover duration and ice thickness are highly important and sometimes limiting factors in winter operation of lakes and rivers. The timing and duration of ice phenomena determine navigation, hydraulic construction works in cold period and construction of ice roads. Ice thickness is a major factor in evaluation of the bearing capacity and duration of ice bridges and winter roads for rivers, lakes and reservoirs. The results obtained can be used for optimization of water man- 
agement on lakes and rivers of the APR in autumn-winter and spring periods.

Assessment of changes in the above mentioned characteristics of lake and river ice regime have been made for 52 river sites and five lake sites of the APR based on long-term observation data with homogeneity analysis of long-term series and the detected trends. Such research, including lakes and rivers of the APR, were undertaken earlier and their results are presented, for example, in [2] [3] [4] [12]. In particular, in [2], assessments of changes in the above characteristics for 18 river sites and five lake sites of the APR were provided. Some of these sites have been included in the present paper. However, [2] provides assessments of changes for the period 1980-2008 (2009).

This study found that, for most of the APR sites, reduction in both ice cover duration and maximum ice thickness has occurred over the non-stationary climate period (1980-2014) compared to the previous period (1955-1979). The greatest quantitative changes in the above characteristics occurred in the Eastern Siberia and the Amur River basin. At the same time, there are a few cases of positive dynamics in all the considered regions. One should note also that no cases have been revealed of positive trends in time-series of both the considered characteristics.

\section{References}

[1] IPCC (2014) Summary for Policymakers. In: Climate Change 2014: Mitigation of Climate Change.

[2] Vuglinsky, V. (2017) Assessment of Changes in Ice Regime Characteristics of Russian Rivers under Current Climate Conditions. Natural Resources, 8, 416-431.

[3] Vuglinsky, V.S. and Gronskaya, T.P. (2006) Changes in Ice Regime of Russian Lakes and Rivers and Their Possible Impact on the Economy. In: Modern Problems of Hydrometeorology, Asterion, St. Petersburg, 229-244. (In Russian)

[4] Vuglinsky, V.S. (2014) Assessment of Changes in Ice Regime Characteristics of Water Bodies for Different Regions of the Country under Current Climate Conditions, Vestnic SPbSU: Geography. Geology, 7, 32-45. (In Russian)

[5] Gvozdetsky, N.A. and Mikhailov, N.I. (1970) Physical Geography of the USSR. Asian Part., 512 p. (In Russian)

[6] Recommended Practices on Maintaining State Water Cadastre. Section 1. Surface waters. Issue 3. Part 1. Data on Water Regime and Resources of Surface Waters. 1979. (In Russian)

[7] Gruza, G.V. and Rankova, E.Ya. (2004) Climate Change Identification: Climate State, Variability and Extremes. Meteorology and Hydrology, 4, 50-66. (In Russian)

[8] Shiklomanov, I.A. and Shiklomanov, A.I. (2003) Climate Change and River Inflow to the Arctic Ocean. Water Resources, 30, 645-654. (In Russian)

[9] Georgievsky, V.Yu., Zhuravin, S.A. and Ezhov, A.V. (1995) Assessment of Trends in Hydrometeorological Situation on the Great Russian Plain under the Effect of Climate Variations. Proceedings of American Geophysical Union, 15th Annual Hydrology Day, 47-58.

[10] Water Resources of Russia and Their Use. Ed. By I. A. Shiklomanov, 2008, 600 p. (In Russian) 
[11] Samarov, K.L. (2009) Mathematical Statistics. Manual for Students. Learning Center Resolventa, 30 p. (In Russian)

[12] Vuglinsky, V.S. (2002) Peculiarities of Ice Events in Russian Arctic Rivers. Hydrological Processes, 16, 905-913. 